\title{
Resilience and stability of Cymodocea nodosa seagrass meadows over the last four decades in a Mediterranean lagoon
}

\author{
Marie Garrido $^{\mathrm{a}, 2}$, Céline Lafabrie ${ }^{\mathrm{a}, \mathrm{b}, 1,2}$, Franck Torre ${ }^{\mathrm{c}}$, Catherine Fernandez ${ }^{\mathrm{c}}$, \\ Vanina Pasqualini ${ }^{\mathrm{a}, *}$ \\ ${ }^{a}$ UMR 6134 CNRS Sciences pour l'Environnement, UMS 3514 CNRS, Stella Mare, Université de Corse, BP 52, 20250 Corte, France \\ ${ }^{\mathrm{b}}$ IRD, UMR 5119 ECOSYM, Université Montpellier 2, 34095 Montpellier, France \\ ' Aix-Marseille Université, Institut Méditerranéen de Biodiversité et d'Ecologie (IMBE), UMR-CNRS-IRD 6372, 13331 Marseille, France
}

\section{A R T I C L E I N F O}

\section{Article history:}

Received 9 October 2012

Accepted 31 May 2013

Available online $\mathrm{xxx}$

\section{Keywords:}

Cymodocea nodosa

spatio-temporal dynamics

disturbance

resilience

GIS

Urbino lagoon

\begin{abstract}
A B S T R A C T
Understanding what controls the capacity of a coastal lagoon ecosystem to recover following climatic and anthropogenic perturbations and how these perturbations can alter this capacity is critical to efficient environmental management. The goal of this study was to examine the resilience and stability of Cymodocea nodosa-dominated seagrass meadows in Urbino lagoon (Corsica, Mediterranean Sea) by characterizing the spatio-temporal dynamics of seagrass meadows over a 40 -year period and comparing (anthropogenic and climatic) environmental fluctuations. The spatio-temporal evolution of seagrass meadows was investigated using previous maps $(1973,1979,1990,1994,1996,1999)$ and a 2011 map realized by aerial photography-remote sensing combined with GIS technology. Environmental fluctuation was investigated via physical-chemical parameters (rainfall, water temperature, salinity, turbidity, dissolved oxygen) and human-impact changes (aquaculture, artificial channel). The results showed a severe decline (estimated at $-49 \%$ ) in seagrass meadows between 1973 and 1994 followed by a period of strong recovery (estimated to $+42 \%$ ) between 1994 and 2011. Increased turbidity, induced either by rainfall events, dredging or phytoplankton growth, emerged as the most important driver of the spatiotemporal evolution of Cymodocea nodosa-dominated meadows in Urbino lagoon over the last four decades. Climate events associated to increased turbidity and reduced salinity and temperature could heavily impact seagrass dynamics. This study shows that Urbino lagoon, a system relatively untouched by human impact, shelters seagrass meadows that exhibit high resilience and stability.
\end{abstract}

(c) 2013 Elsevier Ltd. All rights reserved.

\section{Introduction}

Seagrass meadows are one of the most productive coastal communities (Duarte and Chiscano, 1999) and play key ecological roles in lagoon, estuarine and marine ecosystems by providing food and shelter for many important organisms, stabilizing sediments, and regulating nutrient cycles (Hemminga and Duarte, 2000; Larkum et al., 2006; Short et al., 2007). Seagrass meadows thus

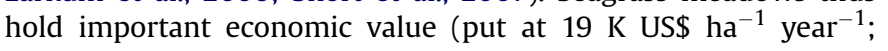
Costanza et al., 1997). However, they are rapidly declining across the globe, with rates increasing from median of $0.9 \% \mathrm{yr}^{-1}$ before 1940 to 7\% after 1990 (Orth et al., 2006a; Waycott et al., 2009).

\footnotetext{
* Corresponding author.

E-mail address: pasquali@univ-corse.fr (V. Pasqualini).

1 Present address: IRD, Faculté des Sciences de Bizerte, 7021 Zarzouna, Tunisia.

2 Equal contributions to the work.
}

Anthropogenic pressures (e.g., industrial, agricultural and aquacultural disturbances) that induce water nutrient enrichment and chemical contamination have damaging effects on seagrass meadows and are now considered the main factors of seagrass decline (Orth et al., 2006a; Burkholder et al., 2007; Waycott et al., 2009). Moreover, climate change is expected to further accelerate seagrass regression in the coming years (Waycott et al., 2009).

Since the mid-20th century, there is a consensus view that lagoons and estuaries count among the most disturbed coastal ecosystems worldwide (De Jonge et al., 2002), which means that seagrass meadows in these coastal areas may be particularly vulnerable. In order to better understand the capacity of an ecosystem to efficiently recover after exposure to perturbations, there is a need for spatial data gathered on long time-scales (Fukami and Wardle, 2005). Measuring rates of increase or decrease in lagoon seagrass surface area, such as via spatio-temporal investigations, could provide useful information on the global evolution of lagoon ecosystems in response to environmental factors (Charpentier et al., 
2005; Bernard et al., 2007; Plus et al., 2010). Folke et al. (2010) defined the dynamics and development of complex social-ecological systems via three aspects: resilience, adaptability and transformability. Changes in system dynamics are called regime shifts (Scheffer et al., 2001), and such shifts may be reversible, irreversible, or effectively irreversible (i.e., not reversible on time-scales of interest to society). Understanding what controls the capacity of an ecosystem to recover following disturbances and how human activities can alter this capacity is critical to efficient ecosystem management (Folke et al., 2004; Hugues et al., 2005; Nyström et al., 2012). In many coastal areas, altered ecosystems such as seagrass may take long to revert to their original state due to new ecological feedbacks that reinforce the degraded state (Nyström et al., 2012). This is of grave concern, as the potentially bi-directional influence of feedbacks can lead to undesirable alternative states that are resilient to restorative efforts (Nyström et al., 2012). For example, a model established by van der Heide et al. (2007) found that altered hydrodynamics was a major driver of the observed lack of Zostera marina recovery following a protist infection combined with eutrophication: when the seagrass cover fell below a threshold, current and wave velocities increased and sediment stabilization was lost, which increased turbidity, reduced the growth and density of the remaining seagrasses, and prevented seagrass recruits from establishing.

Urbino lagoon (Mediterranean Sea, France, Corsica; Fig. 1) offers an interesting case study to better understand the functioning of lagoon systems under anthropogenic and climatic pressures and test seagrass resistance and resilience. Indeed, over the last few decades, the lagoon has been the focus of strong environmental changes (anthropogenic and climatic disturbances) but also of long time-series data recordings on its seagrass meadow surface area and environmental parameters (data from the early 1970s: De Casabianca et al., 1973; SOMIVAC and CTGREF, 1979; Fernandez et al., 2006). The dominant seagrass species in Urbino lagoon is Cymodocea nodosa (Ucria) Ascherson, a subtidal species native to the Mediterranean Sea and extending in the Atlantic northward to Portugal and southward to Senegal, including the Canary Islands (Den Hartog and Kuo, 2006). Cymodocea nodosa can form extensive meadows in shallow and sheltered areas such as lagoons (Terrados and Ros, 1992; Ribera et al., 1997).

The objectives of the present study were (1) to characterize the spatio-temporal dynamics of Cymodocea nodosa-dominated seagrass meadows over the last 40 years in Urbino lagoon, and (2) to investigate the possible causes of the observed variations through comparisons with environmental fluctuations (anthropogenic and climatic). The resilience capacity of the system was discussed in light of the findings.

\section{Material and methods}

\subsection{Study site}

Urbino lagoon is located on the eastern coast of Corsica, France (Mediterranean Sea; $42^{\circ} 03^{\prime} \mathrm{N} ; 9^{\circ} 28^{\prime} \mathrm{E}$; Fig. 1). This lagoon is under the influence of a Mediterranean climate, with strong and unpredictable rainfall fluctuations from one year to the next (Fernandez et al., 2006). In 2007, Urbino lagoon was acquired by the Conservatoire du Littoral, a French public agency promoting the conservation of threatened coastal habitats. The lagoon is managed by the regional public agency Conseil Général de la Haute-Corse, and in 2009 it was included in the RAMSAR list of wetlands of international importance. With a surface area of $7.6 \mathrm{~km}^{2}$ and a sub-circular shape, the lagoon has an average depth of $5 \mathrm{~m}$ (maximum depth: $\approx-10 \mathrm{~m}$ ). Its watershed area is small $\left(31 \mathrm{~km}^{2}\right)$, resulting in a characteristically highly homogeneous water mass (euryhaline lagoon; Pasqualini et al., 2006). Over the course of the year, water salinity and temperature vary between 26 and 44 PSU and 6 and $31{ }^{\circ} \mathrm{C}$, respectively (see Pasqualini et al., 2006; Fernandez et al., 2006). Urbino lagoon is exposed to moderate anthropogenic pressure, mainly agricultureand aquaculture-induced pressures. Agriculture (orchards, vineyards) takes place near the catchment area, while aquaculture occurred from 1990 to 2002 and represented 150-250 and $40 \mathrm{t} \mathrm{yr}^{-1}$ of fish (Dicentrarchus labrax and Sparus aurata) and shellish production, respectively. Urbino lagoon is linked to the sea by an artificial channel, in the north-eastern part (Fig. 1). This artificial channel was made in the early 1970s and given regular heavy maintenance during the fish-farming period (1990-2002), but the maintenance effort has tailed off since (pers. com. J.L. Guaitella).

\subsection{Seagrass mapping}

There are earlier maps of the main seagrass meadows and bottom types in Urbino lagoon. The two oldest maps were produced by De Casabianca et al. (1973) and SOMIVAC and CTGREF (1979) at a 1:20,000 scale, based mainly in situ observations. We scanned and georeferenced each map using ArcGis 9.3 (ESRI $\left.{ }^{\circledR}\right)$ with Lambert 93 coordinates. Only areas of seagrass meadows were indicated on the maps. For the present study, the seagrass areas of the De Casabianca et al. (1973) and SOMIVAC and CTGREF (1979) maps were redrawn in vector format tracing polygons on the

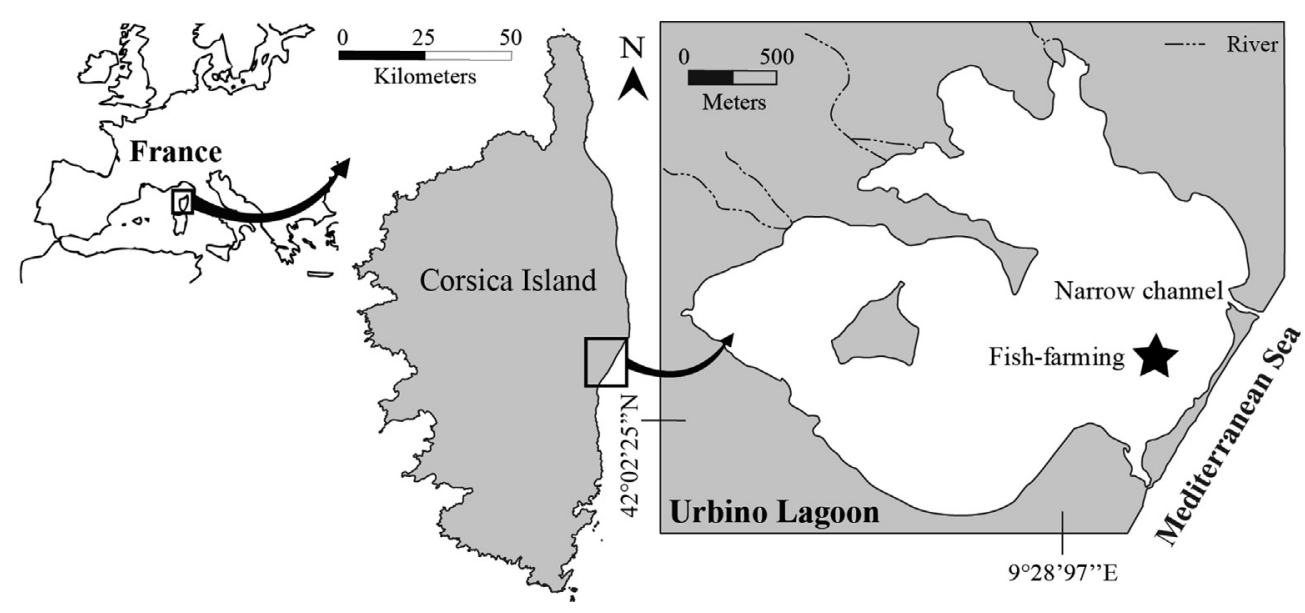

Fig. 1. Location of Urbino lagoon (Corsica, France). 
scanned and georeferenced maps. Fernandez et al. (2006) made accurate maps of Urbino lagoon for 1990, 1994, 1996 and 1999. These maps distinguished four main bottom types: (1) clear sand bottom, (2) pebble bottom and coarse shell, (3) seagrass meadows (essentially Cymodocea nodosa), and (4) silt bottom. Image processing was made from aerial photographs using MULTISCOPE software (version 2.4, Matra Cap System and Information ${ }^{\circledR}$ ), and according to the method described in Pasqualini et al. (1997). This technique combines a high level of precision and rapid processing (Pasqualini et al., 1997, 2001; Fernandez et al., 2006). Briefly, three images, corresponding to three different layers (i.e., red, green and blue), were obtained from aerial photographs. The terrestrial domain was eliminated on the raw image by delimiting the shoreline with closed polygons. The dynamics of each layer was adjusted by enhancing image contrast (linear contrast enhancement) to improve precision and clarity. Principal Component Analysis (PCA) was run on the green and blue layers. A supervised classification (by generalized hypercube) was applied to the coloured composition using both the $0-2$ and $2-5 \mathrm{~m}$ depth layers in order to avoid any depth-related confusion between classes. The polygons were then positioned based on in situ field observations. Occasional corrections were made to the final images on the basis of field data, especially when the meadows were down to $5 \mathrm{~m}$ depth. For the present study, all four of Fernandez et al.'s (2006) maps were georeferenced with Lambert 93 coordinates and converted to a vector format in a GIS database.

The current distribution of meadows and other bottom types within Urbino lagoon was mapped from colour aerial photographs (June 2011, 1:5000 scale; International Air Photo ${ }^{\circledR}$ ) and field observations (June 2011, 45 points and 8 transects recorded with a differential GPS). Image processing (ENVI ${ }^{\circledR}$ software) made it possible to discriminate four main bottom types: seagrass meadow, sand, pebble, silt. The field observations were used for the image processing classification in order to produce a thematic map according to the method described in Pasqualini et al. (1997). The obtained map was then georeferenced with Lambert 93 coordinates, and converted to a vector format in a GIS database.
The spatio-temporal evolution of the seagrass meadows was determined by comparing the successive maps two-by-two using absence-presence data for each pixel. We thus obtained 6 diachronic maps reporting seagrass evolution (i.e., progression, stability, regression) during the successive time intervals investigated, i.e., maps for 1973-1979, 1979-1990, 1990-1994, 19941996, 1996-1999 and 1999-2011. The spatio-temporal analyses (mapping and surface area calculations) were performed by geotreatment, using ArcGis 9.30 software (ESRI ${ }^{\circledR}$ ).

\subsection{Environmental data}

Urbino lagoon is a fairly homogeneous water body, both horizontally and vertically. When stratification occurs, changes with depth only concern the deeper parts, where the studied species are absent. Meteorological data (monthly rainfall) for the year 1970 were provided by the Météo-France weather stations located near the lagoon. The time-series data was environmental water parameters measured in the subsurface of the central part of the lagoon. Water temperature, salinity, turbidity and dissolved oxygen were recorded weekly or bimonthly from 1987 to 2011 (fish farming, IFREMER and University of Corsica data). Some data are missing for dissolved oxygen. Ammonium and chlorophyll $a$ concentration data are available for summer months from 2002 to 2011 (except 2005; IFREMER and University of Corsica data).

\subsection{Data analysis}

Based on the available data, statistical analysis (relationship between environmental data and seagrass meadow) was performed on precipitation, water temperature, turbidity, salinity and dissolved oxygen. Ammonium and chlorophyll $a$ could not be taken into account given the low number of data.

A first table ( $\left.\mathbf{N}_{i j k}\right)$ was computed giving the number of pixels in spatial unit $i$ with evolution $j$ during period $k$ (Fig. 2). Spatial units were defined according to a 5-by-4 grid from which only 15 were of interest. Index $\mathbf{i}$ runs from 1 to 15 and stands for the spatial units.

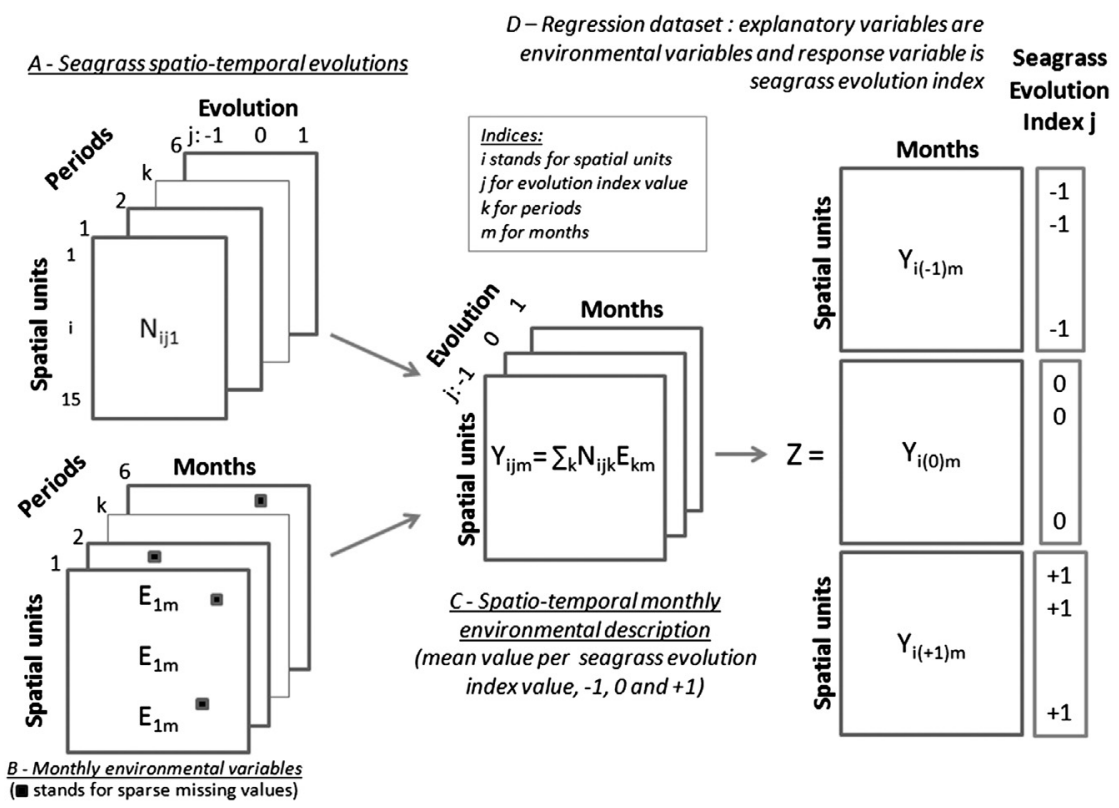

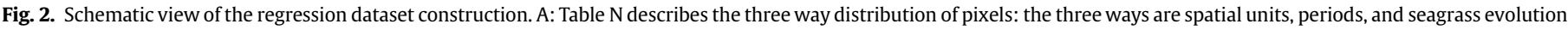

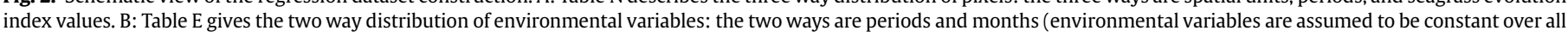

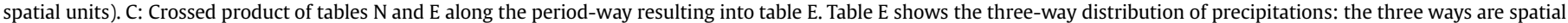

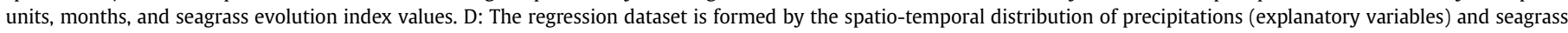
evolution index (response variable). Index $i$ stands for spatial units, $j$ for evolution index value, $k$ for periods, $m$ for months. See text for details on the computation process. 
Index $\mathbf{j}$ takes value $-1,0$ or +1 and stands for regression, stable or decline in evolution. Index $\mathbf{k}$ runs from 1 to 6 and stands for each of the six periods available, starting in May and ending in April. A second table $\left(\mathbf{E}_{k m}\right)$ was computed giving the average of a given environmental variable for month $\mathbf{m}$ during period $\mathbf{k}$. Again, index $\mathbf{k}$ stands for each of the six periods available. Index $\mathbf{m}$ runs from 1 to 12 and stands for the calendar month. A third table $\left(\mathbf{Y}_{\mathrm{ijm}}\right)$ was derived from the cross-product of tables $\mathbf{N}$ and $\mathbf{P}$ according to the formulae:

$\mathbf{Y}_{i j m}=\sum_{k} \mathbf{N}_{i j k} * \mathbf{P}_{k m}$

Table $\mathbf{Y}$ gives the average monthly precipitations for spatial unit $\mathbf{i}$ in month $\mathbf{m}$ and evolution $\mathbf{j}(\mathbf{i}=1$ to $15, \mathbf{j}=-1: 0:+1, \mathbf{m}=1-12$ ). Table $\left(\mathbf{Z}_{i j}, m\right)$ was finally defined as the juxtaposition of the rows of $\left(\mathbf{Y}_{i m}\right)_{j}$ tables $(\mathbf{j}=-1: 0: 1)$. Table $Z$ contains potentially explanatory variables $\mathbf{Z}_{m}$ and the response in terms of regression, stability or progression as referred by index $\mathbf{j}$.

A partial least squares regression (PLSR) was performed on the set of monthly environmental variables precipitation, water temperature, turbidity, salinity and dissolved oxygen to explain seagrass evolution index (Wold, 1966; Helland, 1990). PLSR is well suited when a set of highly-correlated explanatory variables are considered as leading to unstable estimation of classical multiple linear regression coefficients. It yields one-at-a-time uncorrelated latent variables which are linear combinations of the set of initial variables. At each step, the new latent variable maximizes the covariance with response variable. Two latent variables were considered according to the AIC parsimony criterium. This approach was complemented by a geographically-weighted regression (GWR, Fotheringham et al., 2002; Wheeler, 2007) that estimates spatially-varying coefficients. Spatial kernel weights are applied to observations using the estimated or supplied kernel bandwidth to calibrate local models at each datapoint. Bandwidth was estimated by cross-validation against an exponential kernel function.

PLSR and GWR were performed using R software (R Development Core Team, 2011). PLSR was computed using the plsRglm package (Meyer et al., 2010). GWR was issued from the gwrr package (Fotheringham et al., 2002). Spatially-varying coefficients were represented graphically using package ade4 (Dray and Dufour, 2007).

\section{Results}

In June 2011, seagrass meadows formed a discontinuous belt along the edge of the lagoon reaching up to $300 \mathrm{~m}$ wide in places (Fig. 3). The meadows mainly occurred in shallow areas (0-5 m depth) and represented a total surface of $2.02 \mathrm{~km}^{2}$ (27.8\% of the total surface area of the lagoon). They were dominated by Cymodocea nodosa, with a few shoots of Zostera noltii and Ruppia cirrhosa occurring locally. Meadows were often associated with Gracilaria sp., especially in the western parts of the lagoon, and with filamentous green algae (mainly Chaetomorpha sp.). These algae were likely to form a light shield for seagrass meadow. Silt occupied almost the entire central region of the lagoon (64.6\% of total surface area; Fig. 3). Clear sand bottom was mainly found on the periphery of the lagoon (6.2\% of total surface area; Fig. 3 ). Pebble bottom and coarse shell were limited to very small pockets, mainly located in the northern part of the lagoon (1.4\% of total surface area; Fig. 3 ).

The temporal evolution of seagrass surface area from 1973 to today showed a decrease between the early 70s and early 90 s followed by an increase until 2011 (Fig. 4). Seagrass surface area evolved from $30.4 \%$ of total surface area in $1973\left(2.24 \mathrm{~km}^{2}\right)$ to a minimum surface area of $14.9 \%$ in $1994\left(1.15 \mathrm{~km}^{2}\right)$, and then evolved to $27.8 \%$ in $2011\left(2.02 \mathrm{~km}^{2}\right)$. The seagrass decline observed between 1973 and 1994 was estimated at 49\% (in terms of seagrass surface area), and the seagrass progression observed between 1994 and 2011 was estimated at $42 \%$. The $1990-1994$ seagrass regression resulted in an increase in silty sediment surface area. In contrast,

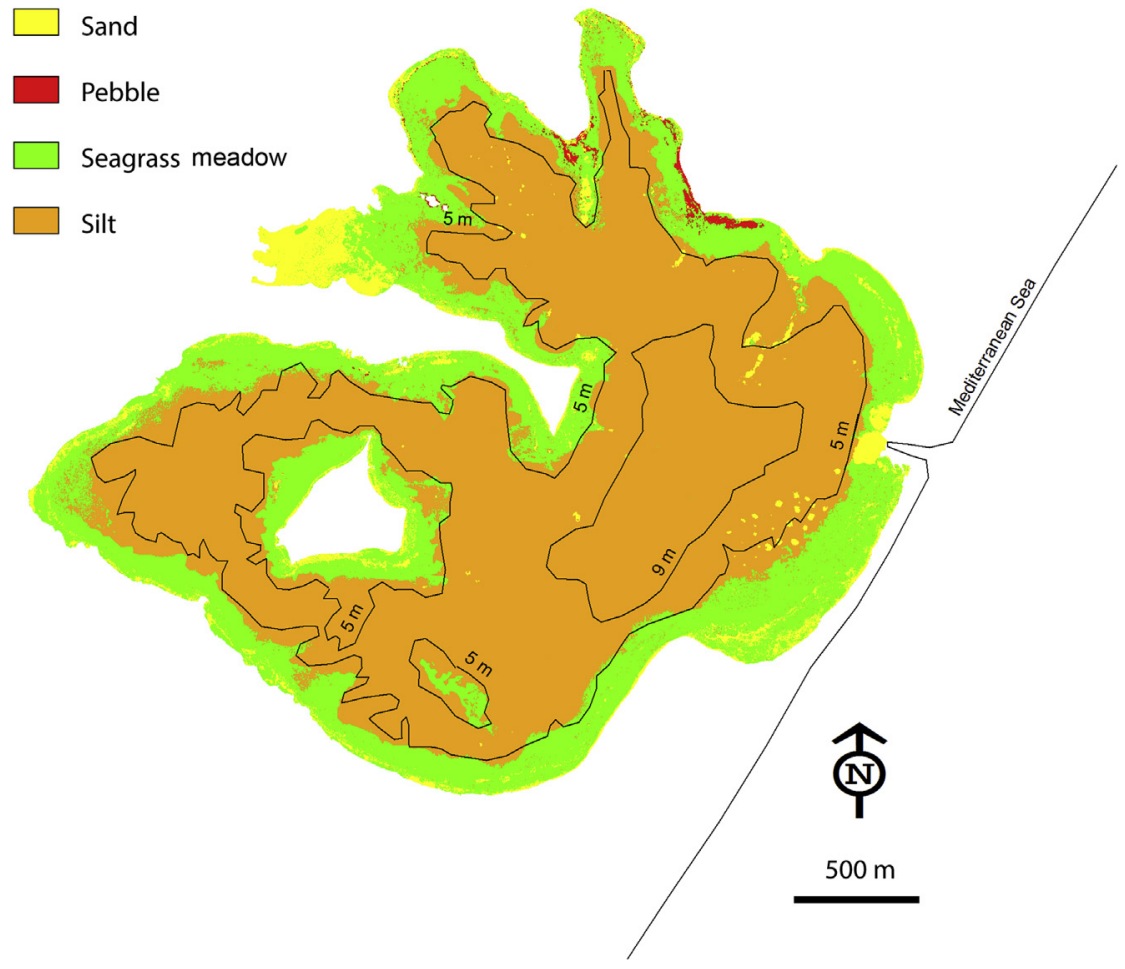

Fig. 3. Map of the spatial distribution of seagrass meadows and bottom types in Urbino lagoon in 2011, obtained by image processing on aerial photographs. 


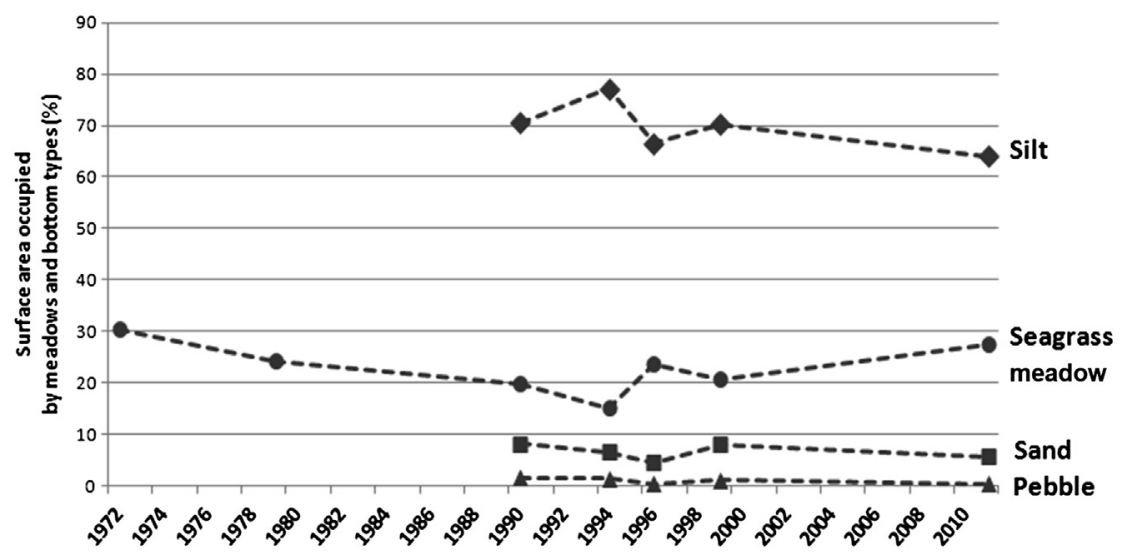

Fig. 4. Evolution of the surface area occupied by seagrass meadows and the different bottom types (\%) in Urbino lagoon between 1973 and 2011.

the slight seagrass regression in 1996-1999 not only resulted in an increase of silty sediment surface area but also in increases in sandy sediment and pebble surface areas (Fig. 4).

Cymodocea nodosa regressions and progressions were spatially heterogeneous. The strong decline that was observed between 1973 and 1979 mainly concerned the eastern part of the lagoon (Fig. 5). Regressions were also observed in the lagoon between 1979 and 1990, but the spatial evolution showed a recolonization of seagrass meadow in the western part of the lagoon (Fig. 5). Seagrass regression continued between 1990 and 1994 but tended to be located in the eastern part of the lagoon (on the side of the watershed; Fig. 5). The progression observed between 1994 and 1996, and the slight decline observed between 1996 and 1999 concerned the whole lagoon (Fig. 5). Finally, sour data showed seagrass progression over the 1999-2011 period.

The temporal evolution of environmental parameters showed high inter-annual variability (Fig. 6). Concerning precipitations, rainfall patterns varied greatly from year to year. During the study period, seven intense precipitation events occurred, with rainfall exceeding $350 \mathrm{~mm}$ in December 1972, October 1979, September 1989, November 1993, September 2006, October 2007 and November 2008 (Fig. 6) whereas annual rainfall generally varies between 400 and $900 \mathrm{~mm}$. Between 1987 and 2011, water temperature did not substantially differ from one year to the next for any given season. The highest value was observed in July $1995\left(31.7^{\circ} \mathrm{C}\right)$ whereas the lowest value was recorded in January $2006\left(6.0^{\circ} \mathrm{C}\right)$. No temperature anomalies were recorded, even after the freshwater runoff event observed in November 1993 for example (Fig. 6). Salinity generally fluctuated between 30 and 38 PSU (Fig. 6). The lowest salinity value was recorded in November 1993 (23 PSU), but salinity values were also pretty low in January 1997, February 1999, September 2006, January 2008 and January 2009. Turbidity generally varied between 0 and 4 NTU, but values higher than 5 NTU were found several times (May 1988, November 1993, November 1999, January 2006, December 2006/January 2007, November/December 2007, November 2008, and April 2011). Regarding dissolved oxygen
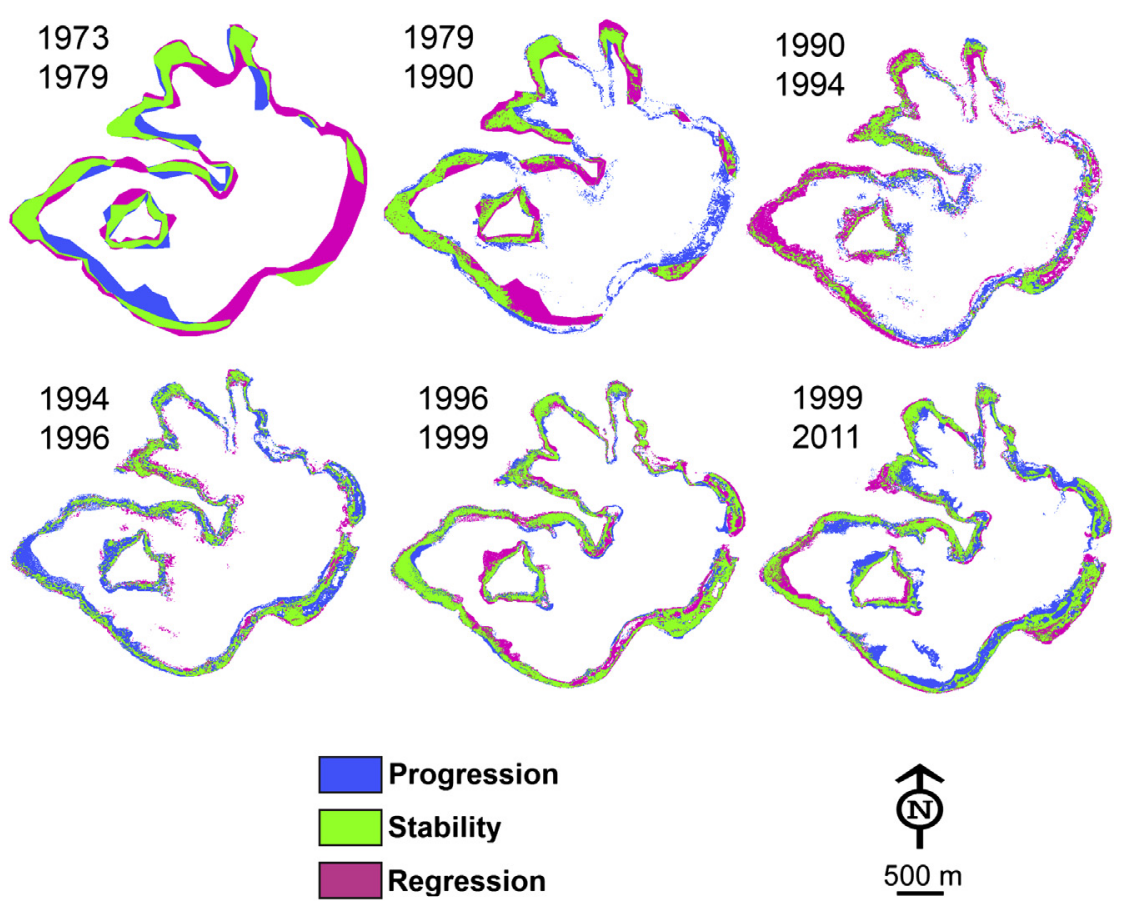

Fig. 5. Spatial evolution of seagrass meadows in Urbino lagoon, between 1973 and 2011. 

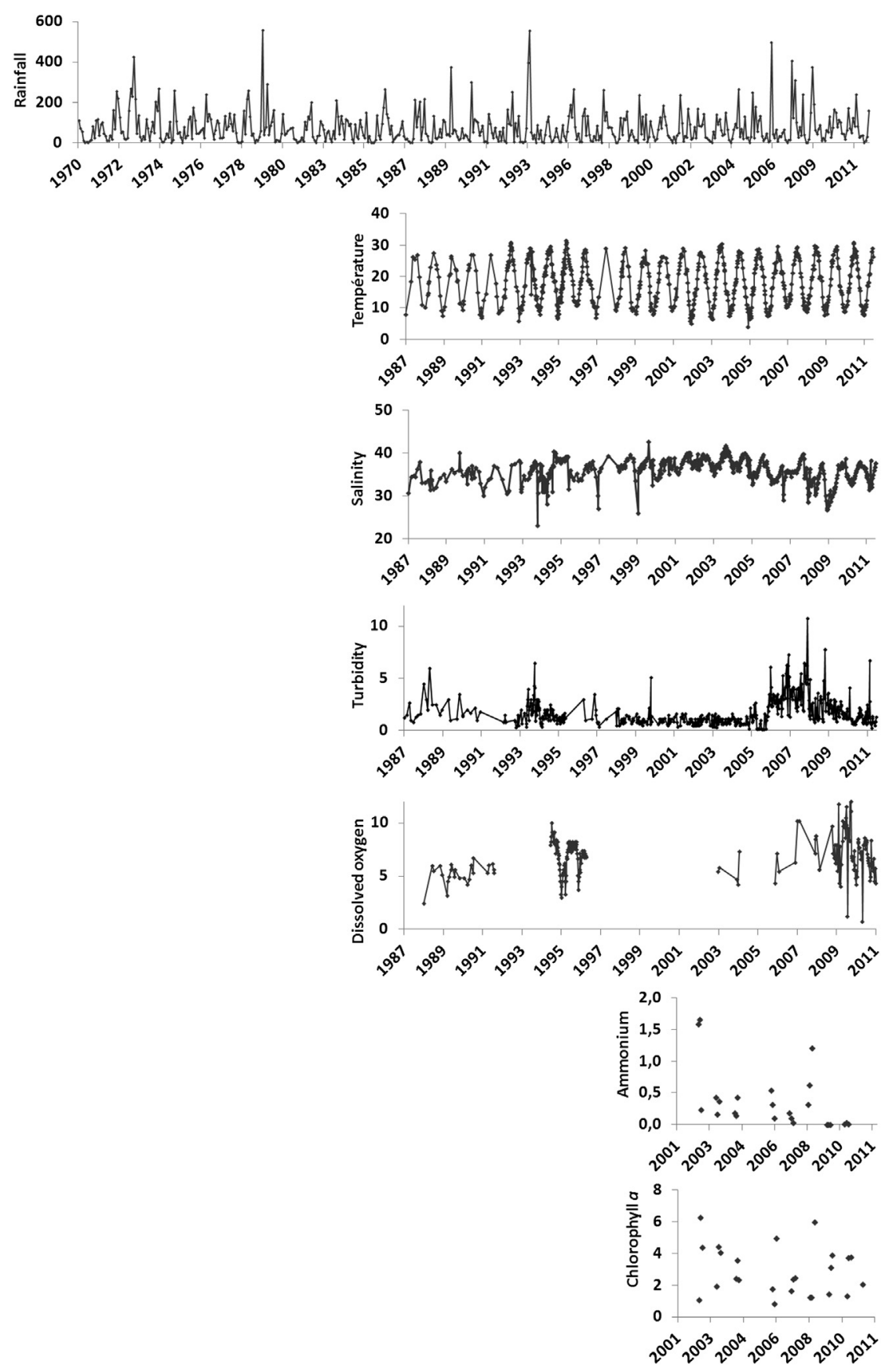

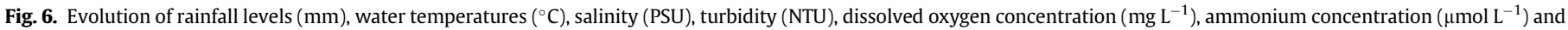
chlorophyll $a$ concentration $\left(\mu \mathrm{g} \mathrm{L}^{-1}\right.$ ) in Urbino lagoon, between 1973 and 2011.

levels, the data only concerned a few periods between 1987 and 2011. Dissolved oxygen concentrations globally varied between 3 and $10 \mathrm{mg} \mathrm{L}^{-1}$, with drops during summer. Between 2002 and 2011, ammonium and chlorophyll $a$ summer concentrations ranged from 0 to $1.6 \mu \mathrm{mol} \mathrm{L}{ }^{-1}$ and 0.9 to $6.3 \mu \mathrm{g} / \mathrm{L}^{-1}$, respectively.

PLSR between monthly environmental data (precipitation, water temperature, turbidity, salinity and dissolved oxygen) and seagrass evolution highlighted an important influence of several environmental parameters on seagrass progression and regression in Urbino lagoon (Fig. 7). Seagrass regressions were strongly linked to winter precipitation (Fig. 7), especially in the northwestern part of the lagoon (Fig. 8). In contrast, seagrass progressions were positively related to mild temperatures in winter (February) and early spring (April), especially in the northwestern part of the lagoon (Figs. 7 and 8). The high water turbidities in summer months, especially August, appeared unfavourable to seagrass progression, especially in the northwestern part of the lagoon (Figs. 7 and 8), and the turbidity increases observed for some winter months negatively influenced seagrass distribution (Fig. 7). Note that the result found for September appeared inconsistent with these general patterns as it did not fit the annual curve (Fig. 7). It clearly appears that seagrass evolution within the lagoon was strongly linked to the salinities increases occurring in autumn, winter and early spring months, especially in the northwest part of 


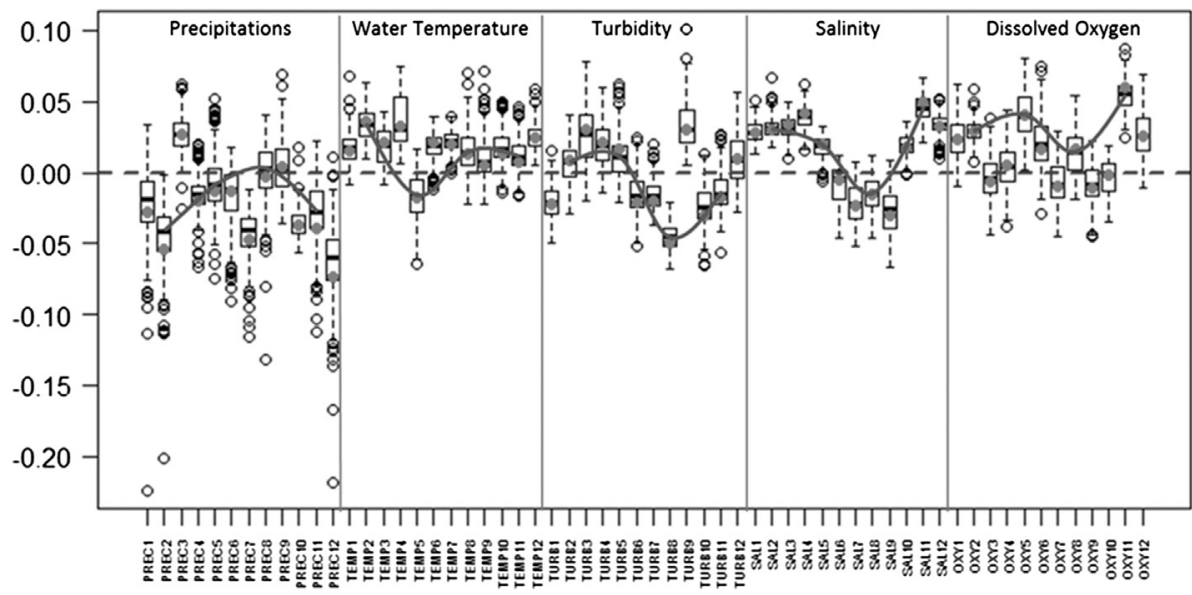

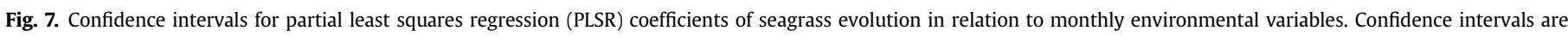

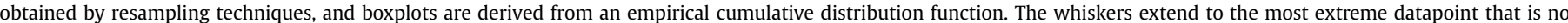

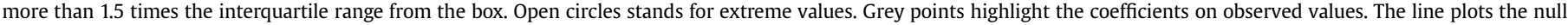
coefficient and helps graphically visualize the significance of the corresponding environmental variable.

the lagoon (Figs. 7 and 8). Furthermore, increases in oxygen levels appeared particularly favourable to seagrass development, especially in the northwest and center of the lagoon (Figs. 7 and 8).

\section{Discussion}

Monitoring the spatial evolution of seagrass meadows over time is of primary importance for identifying which factors are likely to control the capacity of the ecosystem to recover after disturbances (natural and/or anthropogenic), and hence for efficient coastal environment management. There is little available literature on the spatio-temporal dynamics of seagrass meadows over long timeperiods (Charpentier et al., 2005; Orth et al., 2006b; Bernard et al., 2007; Sfriso and Facca, 2007). Here, we report evolutions in spatial distribution of Cymodocea nodosa-dominated seagrass meadows in a Mediterranean lagoon over a 40-year time-scale. Our data showed a $49 \%$ regression in seagrass meadow from the early 1970 s to the early 1990 s followed by a $42 \%$ increase from the early 1990s to now. With the exception of a few cases (e.g., seagrass expansion in Isle of Wight Bay: Dennison et al., 2009; seagrass recovery in the Delmarva Coastal Bays, USA: Orth et al., 2006b), studies over the last few decades report drastic declines in seagrass

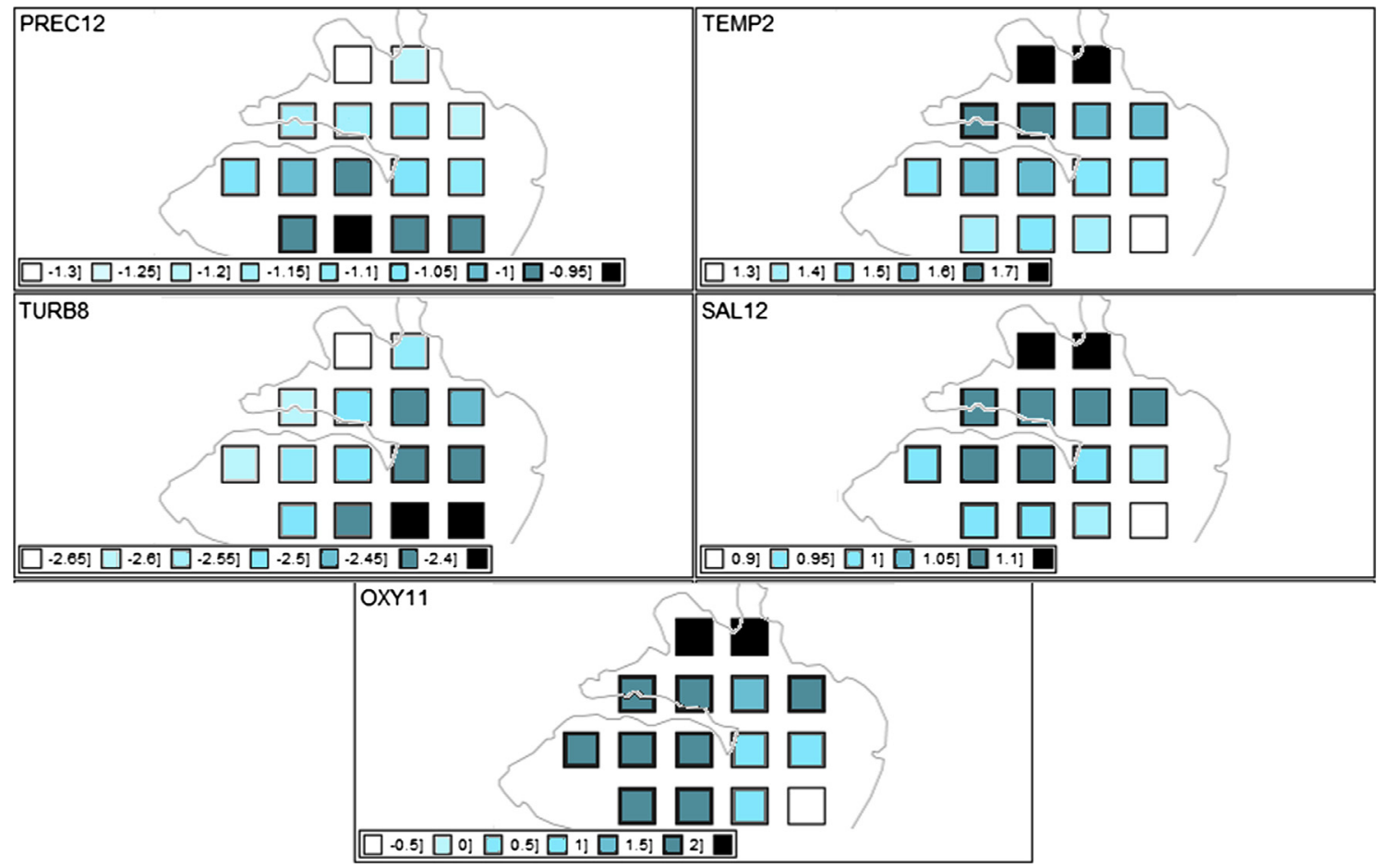

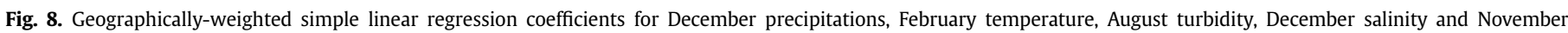

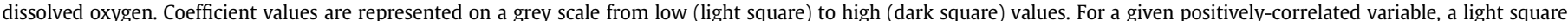

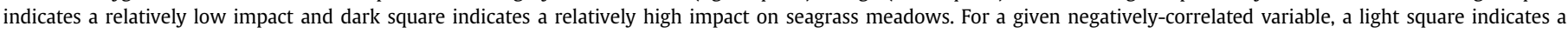
relatively high impact and dark square indicates a relatively low impact on seagrass meadows. 
worldwide (Orth et al., 2006a; Waycott et al., 2009). The seagrass progression found in the Corsican lagoon investigated here thus appears another exceptional case. This lagoon thus represents an interesting study case for evaluating seagrass resistance potential and resilience capacity.

However, the maps investigated for this 40 -year time scale were produced at different levels of precision. As pointed out by Leriche et al. (2004), comparing data from different sources and methods makes it possible that some differences do not reflect changes over time. The older maps (i.e., the 1973 and 1979 maps) were only realized from field data, whereas the more recent maps (i.e., the 1990, 1994, 1996, 1999 and 2011 maps) were realized by imageprocessing aerial photographs. The image processing technique combines a high level of precision and rapid processing for lagoon environments (Pasqualini et al., 1997). These methodological issues warrant careful analysis in the context of monitoring on seagrass meadows and bottom types and when interpreting the data produced. Further caution is warranted when looking at the spatiotemporal evolution of seagrasses in this study, due to the absence of intermediate data between the years of the investigated maps.

The relations between environmental data and seagrass evolution show that in Urbino lagoon, some parameters have a positive influence on seagrass distribution while others have a negative influence-particularly precipitation, for which statistical relationships are almost all negative throughout the year, especially in winter. Geographically-weighted multiple linear regression coefficients for December found a large negative impact of precipitation on seagrass meadows in the northwest of the lagoon, near river arrivals and marsh. Rainfall induces changes in the physicalchemical parameters of the water column (e.g., turbidity, salinity, temperature) and thus can strongly influence the spatial distribution of seagrasses, as previously reported by several authors (Charpentier et al., 2005; Fernandez et al., 2006; Bernard et al., 2007; Obrador and Pretus, 2010).

Concerning turbidity, our results show a negative influence of summer turbidity on seagrass distribution. Summer turbidity seems to be linked to phytoplankton production (estimated by chlorophyll a concentration), which in Mediterranean lagoons is generally higher in summer months than winter months (Bec et al., 2011). Correlations between chlorophyll $a$ and turbidity have already been observed in other coastal ecosystems and have been found to negatively impact seagrasses (Gilbes et al., 1996; Fertig et al., 2013). However, increased turbidity may also be linked to sediment resuspension events (e.g., storms, dredging operations). During our study, we recorded several instances of events inducing turbidity increases. Intense winter precipitations increased shortterm freshwater inputs into the lagoon and thus water-column turbidity. Fernandez et al. (2006) attributed the 1994 Cymodocea nodosa regression to the heavy November 1993 rainfall event. Such heavy rainfall events occur about once every 50 years (MétéoFrance data); the November 1993 rainfall event was the heaviest since 1958. Dredging events induced sediment resuspension causing a reduction of light penetration (in early 1970 for the opening of the artificial channel in the northeast of the lagoon, and which was almost certainly responsible for the seagrass regression observed between 1973 and 1979; Erftemeijer and Lewis, 2006). Indeed, light reductions have often been linked with lower shoot densities and biomass, reduced depth penetration, slower growth rates, stunted morphology and higher mortalities of seagrass in coastal lagoons (Fertig et al., 2013). Therefore, turbidity (rainfallinduced, dredging-induced, or due to recurrent phytoplankton production) may be one of the main drivers of seagrass regression in Urbino lagoon.

For salinity, our results pointed to a positive influence of high salinity in winter (from November to April, where salinity levels are similar to those of coastal marine environments) for good development of seagrass surfaces, and a negative influence of very high salinity in summer. This indicates too that the strong precipitation events (with decreasing salinity) could be detrimental to seagrass development. Even though Cymodocea nodosa is considered euryhaline (Caye and Meinesz, 1986), its photosynthesis and growth are altered following exposure to chronic salinity increases (SandovalGil et al., 2012). Often, turbidity and salinity are linked and act in interaction. Charpentier et al. (2005) found that declines in Zostera noltii in Vaccarès lagoon (Camargue, South of France) was related to the combined action of turbidity with salinity. Indeed, drops in salinity can slow the settling velocity of suspended sediment particles, which would extend the duration of turbidity phenomena and thus participate, albeit indirectly, to seagrass declines. Surprisingly, strong rainfalls also occurred in Urbino lagoon in 2006, 2007 and 2008 but did not result in regressions in 2011. Indeed, seagrass surface area actually increased between 1999 and 2011. These results suggest that even though rainfall events induce important changes in the physical-chemical characteristics of the water column, Cymodocea nodosa can still adapt within threshold levels, and that seagrass ecosystems thus seem to exhibit a high degree of resilience and stability towards climatic and hydrological disturbances.

Our results show a beneficial influence of oxygen level on seagrass meadow, particularly in the northwest of the lagoon which featured the most confined areas, away from intake seawater. High water column oxygen concentrations (associated with moderate temperature and sediments of low organic content and oxygen consumption) are able to support aerobic metabolism within leaves, rhizomes and roots of seagrasses such as Zostera marina (Pulido and Borum, 2010).

High temperatures in winter and early spring also had a positive influence on seagrass development, which mirrors the pattern generally observed, as temperature is a major factor controlling Cymodocea nodosa leaf development (Malea and Zidikou, 2011).

Other parameters not analyzed in this study due to a lack of data can negatively impact seagrass distribution. The most significant is eutrophication (Burkholder et al., 2007). Cymodocea nodosa is able to grow under a wide range of water nutrient concentrations (Perez et al., 1994) and can survive under reducing sediment conditions (Terrados et al., 1999). Given the absence of nutrient data in the lagoon during the period of fish-farming activity (1990-2002; low ammonium concentrations have been found since 2000), it is difficult to conclude on the impact of aquaculture on seagrass. However, seagrass meadows did increase during this period, and siltation and organic matter inputs were mainly observed close to and under cages where seagrasses were absent (personal observations). Based on these results, eutrophication may not be the cause of the seagrass decline observed in Urbino lagoon during the study period.

Herbivore pressure may also have effects on the spatio-temporal evolution of seagrass meadow. Consumption of Cymodocea nodosa by grazers can reach $45 \%$ of production, and the role of herbivores in controlling seagrass production increases along a gradient from exposed to sheltered meadows (Cebrian et al., 1996). In Urbino lagoon, the sea urchin Paracentrotus lividus is the predominant grazer of Cymodocea nodosa meadows (Fernandez et al., 2012). It can consume up to $100 \%$ of seagrass production in some conditions, and can even overgraze at a density of around $10-30$ ind $/ \mathrm{m}^{2}$ (Fernandez et al., 2012). Nevertheless, urchin populations vary greatly in lagoon environments like Urbino lagoon. In this lagoon, the urchin population varied from 6 to 3 million individuals in the 1990s (Fernandez et al., 2006). These variations are due to massive mortality but also to low recruitment in some years. In the 2000s, sea urchins disappeared completely from Urbino lagoon (personal 
observations), possibly caused by (1) low maintenance of the artificial channel since the early 2000s (after closure of the fish farming activity) resulting in poor water circulation within the lagoon; and/ or (2) the frequent rainfall that occurred in 2006, 2007 and 2008 in the lagoon (sea urchins appear highly sensitive to salinity decreases; Fernandez et al., 2006). The recent rapid progression of Cymodocea nodosa in the lagoon between 1999 and 2011 is likely linked to the total disappearance of sea urchins. Sea urchin populations seem to be less stable than Cymodocea nodosa. In the long term, over the 20 years for which data on urchins are available, grazing still seemed limited (with a mean consumption of $1.4 \%$ of seagrass production), except for the odd overgrazing events (always spatially and temporally limited), which were in fact observed only twice, in 1990 and 1999 (Fernandez and Caltagirone, 1990; Fernandez et al., 2012), due to migration from the pebble bottom to Cymodocea beds near the artificial channel. For these reasons, the long-term view is that the urchin population in this lagoon seems to have less impact than other phenomena such as flooding.

In summary, this study highlights that turbidity increases, induced either by rainfall events, dredging or phytoplankton growth, is the most important factor explaining the spatiotemporal dynamics of Cymodocea nodosa populations over the last four decades in the Urbino lagoon. Climate events driving increased turbidity, reduced salinity and temperature has clear impact on the dynamics of seagrass meadows. Nevertheless, seagrass meadows in this lagoon show a high degree of resilience. This system stability may be attributed to the characteristic fast growth and high colonization capacity of the Cymodocea nodosa species. Patterns of change from one ecosystem state to another tell us nothing per se about rate of recovery to the initial state. In some cases, when negative feedbacks predominate, regime shifts can easily lead the system to its initial state, but in other cases, lags in recovery can prove protracted, and the ecosystem may remain locked into a degraded state, which can be described as an alternative stable state (Nyström et al., 2012). Alternative stable states are also often produced by positive feedbacks. Our study illustrates that the ecosystem studied is actually stable and presents negative feedbacks without any regime shifts. Pulse (e.g., storms, hurricanes) or continuous (e.g., fishing, eutrophication) perturbations can overwhelm negative feedbacks, enabling positive feedbacks to dominate (Nyström et al., 2012). A major challenge for coastal researchers and managers is to understand the interactions among these multiple stressors (Vinebrooke et al., 2004). Climate change, inducing physical and ecological changes within coastal lagoons, forces both natural and human communities to adapt. With the increasing intensity of climate change, it is thought that such climatic events will become more frequent, particularly in the Mediterranean region (Christensen and Christensen, 2004). Increased rainfall into coastal lagoons would generate substantial fluctuations in turbidity but also in salinity and temperature that may affect the resilience capacity of Cymodocea nodosa and ultimately lead to its disappearance. However, the ability of natural communities to successfully adapt to changing conditions will be influenced by human management actions.

\section{Acknowledgements}

This study received financial support from the European ZOUMGEST program "ZOne UMide: sistemi GESTionali per integrare le attività antropiche e la tutela della natura" between France and Italy and the Conseil Général de la Haute-Corse. We thank our colleagues from the University of Corsica and the Conseil Général de la Haute-Corse for their assistance with the fieldwork, J.L. Guaitella and L. Tarallo (fishers in Urbino lagoon) for their help during field investigations and their valuable information on the study site, and
E. Dumas (research engineer at the Aix-Marseille University, IMBE) for her skill on spatial data processing. We also thank the reviewers for their helpful comments and suggestions that greatly improved this manuscript.

\section{References}

Bec, B., Collos, Y., Souchu, P., Vaquer, A., Lautier, J., Fiandrino, A., Benau, L., Orsoni, V., Laugier, T., 2011. Distribution of picophytoplankton and nanophytoplankton along an anthropogenic eutrophication gradient in French Mediterranean coastal lagoons. Aquatic Microbial Ecology 63, 29-45.

Bernard, G., Boudouresque, C.F., Picon, P., 2007. Long term changes in Zostera meadows in the Berre lagoon (Provence, Mediterranean Sea). Estuarine, Coastal and Shelf Science 73, 617-629.

Burkholder, J.M., Tomasko, D.A., Touchette, B.W., 2007. Seagrasses and eutrophication. Journal of Experimental Marine Biology and Ecology 350, 46-72.

Caye, G., Meinesz, A., 1986. Experimental study of seed germination in the seagrass Cymodocea nodosa. Aquatic Botany 26, 79-87.

Cebrian, J., Duarte, C.M., Marba, N., 1996. Herbivory on the seagrass Cymodocea nodosa (Ucria) Ascherson in contrasting Spanish Mediterranean habitats. Journal of Experimental Marine Biology and Ecology 204, 103-111.

Charpentier, A., Grillas, P., Lescuyer, F., Coulet, E., Auby, I., 2005. Spatio-temporal dynamics of a Zostera noltii dominated community over a period of fluctuating salinity in a shallow lagoon, Southern France. Estuarine, Coastal and Shelf Science $64,307-315$.

Christensen, O.B., Christensen, J.H., 2004. Intensification of extreme European summer precipitation in warmer climate. Global Planet Change 44, 107-117.

Costanza, R., d'Arge, R., de Groot, R., Farber, S., Grasso, M., Hannon, B., Limburg, K., Naeem, S., O'Neill, R.V., Paruelo, J., Raskin, R.G., Sutton, P., van den Belt, M., 1997. The value of the world's ecosystem services and natural capital. Nature 387, 253-260.

De Casabianca, M.L., Kiener, A., Huve, H., 1973. Biotopes et biocénoses des étangs saumâtres corses: Biguglia, Diana, Urbino, Palo. Vie et Milieu 23, 187-227.

De Jonge, V.N., Elliott, M., Orive, E., 2002. Causes, historical development, effects and future challenges of a common environmental problem: eutrophication. Hydrobiologia 475/476, 1-19.

Den Hartog, C., Kuo, J., 2006. Taxonomy and biogeography of seagrasses. In: Larkum, W.D., Orth, R.J., Duarte, C.M. (Eds.), Seagrasses: Biology, Ecology and Conservation, pp. 1-23. (Chapter1).

Dennison, W.C., Thomas, J.E., Cain, C.J., Carruthers, T.J.B., Hall, M.R., Jesien, R.V., Wazniak, C.E., Wilson, D.E., 2009. Shifting Sands: Environmental and Cultural Change in Maryland's Coastal Bays. University of Maryland Center for Environmental Science. IAN Press, p. 396.

Dray, S., Dufour, A.B., 2007. The ade4 package: implementing the duality diagram for ecologists. Journal of Statistical Software 22, 1-20.

Duarte, C.M., Chiscano, C.L., 1999. Seagrass biomass and production: a reassessment. Aquatic Botany 65, 159-174.

Erftemeijer, P.L.A., Lewis, R.R.R., 2006. Environmental impacts of dredging on seagrasses: a review. Marine Pollution Bulletin 52, 1553-1572.

Fernandez, C., Caltagirone, A., 1990. Données préliminaires sur la population de Paracentrotus lividus de l'étang d'Urbinu (CORSE). Commission internationale pour l'Exploration de la Mer Méditerranée, Monaco 32 (1), 37.

Fernandez, C., Pasqualini, V., Boudouresque, C.F., Johnson, M., Ferrat, L., Caltagirone, A., Mouillot, D., 2006. Effect of an exceptional rainfall event in a Mediterranean coastal lagoon. Estuarine, Coastal and Shelf Science 68, 259-270.

Fernandez, C., Ferrat, L., Pergent, G., Pasqualini, V., 2012. Sea urchin-seagrasses interactions: trophic links in a benthic ecosystem from a coastal lagoon. Hydrobiologia 699, 21-33.

Fertig, B., Kennish, M.J., Sakowicz, G.P., 2013. Changing eelgrass (Zostera marina L.) characteristics in a highly eutrophic temperate coastal lagoon. Aquatic Botany 104, 70-79.

Folke, C., Carpenter, S., Walker, B., Scheffer, M., Elmqvist, T., Gunderson, L., Holling, C.S., 2004. Regime shifts, resilience, and biodiversity in ecosystem management. Annual Review of Ecology, Evolution, and Systematics 35, 557-581.

Folke, C., Carpenter, S.R., Walker, B., Scheffer, M., Chapin, T., Rockström, J., 2010. Resilience thinking: integrating resilience, adaptability and transformability. Ecology and Society 15, 20.

Fotheringham, A.S., Brunsdon, C., Charlton, M., 2002. Geographically Weighted Regression: The Analysis of Spatially Varying Relationships. John Wiley \& Sons, West Sussex, p. 269.

Fukami, T., Wardle, D.A., 2005. Long-term ecological dynamics: reciprocal insights from natural and anthropogenic gradients. Proceedings of the Royal Society B 272, 2105-2115.

Gilbes, F., Lopez, J.M., Yoshioka, P.M., 1996. Spatial and temporal variations of phytoplankton chlorophyll $a$ and suspended particulate matter in Mayagauez Bay, Puerto Rico. Journal of Plankton Research 18, 29-43.

Helland, I.S., 1990. PLS regression and statistical models. Scandinavian Journal of Statistics 17, 97-114.

Hemminga, M.A., Duarte, C.M., 2000. Seagrass Ecology. Cambridge University Press, Cambridge, UK, p. 298.

Hughes, T.P., Bellwood, D.R., Folke, C., Steneck, R.S., Wilson, J., 2005. New paradigms for supporting the resilience of marine ecosystems. Trends in Ecology \& Evolution 20, 380-386. 
Larkum, A.W.D., Orth, R.J., Duarte, C.M., 2006. Seagrasses: Biology, Ecology and Conservation. Springer Verlag, Berlin, p. 691.

Leriche, A., Boudouresque, C.F., Guillaume, B., Bonhomme, P., Denis, J., 2004. A onecentury suite of seagrass bed maps: can we trust ancient maps? Estuarine, Coastal and Shelf Science 59, 353-362.

Malea, P., Zikidou, C., 2011. Temporal variation in biomass partitioning of the seagrass Cymodocea nodosa at the Gulf of Thessaloniki, Greece. Journal of Biological Research-Thessaloniki 15, 75-90.

Meyer, N., Maumy-Bertrand, M., Bertrand, F., 2010. Comparaison de la régression PLS et de la régression logistique PLS: application aux données d'allélotypage. Journal de la Société Française de Statistique 151, 1-18.

Nyström, M., Norström, A.V., Blenckner, T., de la Torre-Castro, M., Eklöf, J.S., Folke, C. Österblom, H., Steneck, R.S., Thyresson, M., Troell, M., 2012. Confronting feedbacks of degraded marine ecosystems. Ecosystems 15, 695-710.

Obrador, B., Pretus, J.L., 2010. Spatiotemporal dynamics of submerged macrophytes in a Mediterranean coastal lagoon. Estuarine, Coastal and Shelf Science 87, 145-155.

Orth, R.J., Carruthers, T.J.B., Dennison, W.C., Duarte, C.M., Fourqurean, J.W. Heck, K.L., Hughes, A.R., Kendrick, G.A., Kenworthy, W.J., Olyarnik, S., Short, F.T., Waycott, M., Williams, S.L., 2006a. A global crisis for seagrass ecosystems. Bioscience 56, 987-996.

Orth, R.J., Luckenbach, M.L., Marion, S.R., Moore, K.A., Wilcox, D.J., 2006b. Seagrass recovery in the Delmarva coastal Bays, USA. Aquatic Botany 84, 26-36.

Pasqualini, V., Pergent-Martini, C., Fernandez, C., Pergent, G., 1997. The use of airborne remote sensing for benthic cartography: advantages and reliability. International Journal of Remote Sensing 18 (5), 1167-1177.

Pasqualini, V., Pergent-Martini, C., Clabaut, P., Marteel, H., Pergent, G., 2001. Integration of aerial remote sensing, photogrammetry and GIS technologies in seagrass mapping. Photogrammetric Engineering and Remote Sensing 67 (1), 99-105.

Pasqualini, V., Pergent-Martini, C., Fernandez, C., Ferrat, L., Tomaszewski, J., Pergent, G., 2006. Wetland monitoring: aquatic plant changes in two Corsican coastal lagoons (Western Mediterranean Sea). Aquatic Conservation: Marine and Freshwater Ecosystems 16, 43-60.

Perez, M., Duarte, C.M., Romero, J., Sand-Jensen, K., Alcoverro, T., 1994. Growth plasticity in Cymodocea nodosa stands: the importance of nutrient supply. Aquatic Botany 47, 249-264.

Plus, M., Dalloyau, S., Trut, G., Auby, I., de Montaudouin, X., Emery, E., Noël, C., Viala, C., 2010. Long-term evolution (1988-2008) of Zostera spp. meadows in Arcachon Bay (Bay of Biscay). Estuarine, Coastal and Shelf Science 87, 357-366.

R Development Core Team, 2011. R: a Language and Environment for Statistical Computing. R Foundation for Statistical Computing, Vienna, Austria, ISBN 3900051-07-0. http://www.R-project.org/.
Ribera, G., Coloreu, M., Rodríguez-Prieto, C., Ballesteros, E., 1997. Phytobenthic assemblages of Addaia Bay (Menorca western Mediterranean): composition and distribution. Botanica Marina 40, 523-532.

Sandoval-Gil, J.M., Marín-Guirao, L., Ruiz, J.M., 2012. The effect of salinity increase on the photosynthesis, growth and survival of the Mediterranean seagrass Cymodocea nodosa. Estuarine, Coastal and Shelf Science 115, 260-271.

Scheffer, M., Carpenter, S., Foley, J., Folke, C., Walker, B., 2001. Catastrophic shifts in ecosystems. Nature 413, 591-596.

Sfriso, A., Facca, C., 2007. Distribution and production of macrophytes and phytoplankton in the lagoon of Venice: comparison of actual and past situation. Hydrobiologia 577, 71-85.

Short, F., Carruthers, T., Dennison, W., Waycott, M., 2007. Global seagrass distribution and diversity: a bioregional model. Journal of Experimental Marine Biology and Ecology 350, 3-20.

SOMIVAC, CTGREF, 1979. Etude des écosystèmes des étangs de Biguglia, Diana, Urbino. Mission interministérielle pour la Protection de l'aménagement de l'Espace Naturel Méditerranéen, France, p. 59.

Terrados, J., Ros, J.D., 1992. Growth and primary production of Cymodocea nodosa (Ucria) Ascherson in a Mediterranean coastal lagoon, the Mar Menor (SE Spain). Aquatic Botany 43, 63-74.

Terrados, J., Duarte, C.M., Kamp-Nielsen, L., Agawin, N.S.R., Gacia, E., Lacamp, D. Fortes, M.D., Borum, J., Lubanski, M., Greve, T., 1999. Are seagrass growth and survival constrained by the reducing conditions of sediment? Aquatic Botany 65, 175-197.

van der Heide, T., van Nes, E.H., Geerling, G.W., Smolders, A.J.P., Bouma, T.J., van Katwijk, M.M., 2007. Positive feedbacks in seagrass ecosystems: implications for success in conservation and restoration. Ecosystems 10, 1311-1322.

Vinebrooke, R.D., Cottingham, K.L., Norberg, J., Scheffer, M., Dodson, S.I., Maberly, S.C., Sommer, U., 2004. Impacts of multiple stressors on biodiversity and ecosystem functioning: the role of species co-tolerance. Oikos 104, 451-457.

Waycott, M., Duarte, C.M., Carruthers, T.J.B., Orth, R.J., Dennison, W.C., Olyarnik, S., Calladine, A., Fourqurean, J.W., Heck Jr., K.L., Hughes, A.R., Kendrick, G.A. Kenworthy, W.J., Short, F.T., Williams, S.L., 2009. Accelerating loss of seagrasses across the globe threatens coastal ecosystems. Proceedings of the National Academy of Sciences 106, 12377-12381.

Wheeler, D.C., 2007. Diagnostic tools and a remedial method for collinearity in geographically weighted regression. Environment and Planning A 39, 24642481.

Wold, H., 1966. Estimation of principal components and related models by iterative least squares. In: Krishnaiaah, P.R. (Ed.), Multivariate Analysis. Academic Press, New York, pp. 391-420. 